\title{
Factors Limiting Afghan and Pakistani Girls' Access and Participation in Education
}

\author{
Hashmatullah Tareen, Attaullah Muhammadi \\ English Department, Pashto Department, Kandahar University, Kandahar, Afghanistan \\ Email: hashmatt2@gmail.com, atta_faizi@yahoo.com
}

How to cite this paper: Tareen, $H$. and Muhammadi, A. (2021) Factors Limiting Afghan and Pakistani Girls' Access and Participation in Education. Open Access Library Journal, 8: e7488.

https://doi.org/10.4236/oalib.1107488

Received: May 4, 2021

Accepted: June 13, 2021

Published: June 16, 2021

Copyright () 2021 by author(s) and Open Access Library Inc.

This work is licensed under the Creative

Commons Attribution International

License (CC BY 4.0).

http://creativecommons.org/licenses/by/4.0/

(c) (i) Open Access

\begin{abstract}
The developed nations around the world pay equal attention to boys' and girls' education. However, girls' education in two neighboring countries like Afghanistan and Pakistan, particularly in Pashtun societies is neglected. In these two countries, girls' education and their lowest enrollment are placed chiefly at the bottom end of educational system in comparison to their male counterparts and girls are likely to be submissive. In this regard, the present paper aims to explore the factors limiting girls' access to education in Afghanistan and Pakistan. The literature drawn from the two countries observed that centuries old norms, poverty, early marriages, lack of female teachers, and logistical and infrastructural obstacles contribute in girls' vulnerability regarding education.
\end{abstract}

\section{Subject Areas \\ Humanities \& Culture}

\section{Keywords}

Afghanistan, Pakistan, Girls' Education, Cultural Norms, Poverty, Early Marriages, Female Teachers

\section{Introduction}

Education is universally acknowledged as a prevailing accelerating aspect that benefits individuals to promote national development. Every civilized society considers the education sector as an indispensable sign of economic and social advancement [1] [2]. For maintaining socio-economic development of a society and a basic instrument for human resources development, education remains one of the vital features. As it enables economic through the broader application of skills, knowledge and creative power of a society. Education, on the other 
hand, reduces poverty, difference and tries to overcome gender differences between males and females [3]. Education, in fact, plays an essential role in capacity building in terms of opportunities that are created and enriched by educated members of the society [2]. In terms of developmental activities of a country, the role of men and women cannot be ignored [1]. Precisely, it is essential for human societies to exploit their human capital to attain social, cultural and economic prosperity. Considering the social impact of education, there is visible evidence that education can substantially reduce crime, improve health, increases political participation and lifetime earnings [4].

Female education, in the developmental process of a country, plays a dominant role and nothing of lasting value can be succeeded without knowing women's potential role [1] [5]. The development of female education is a major issue around the world in all religions and cultures and its practices have led to worldwide debate on how to convey an equal education opportunity for all without any sort of discrimination. Females create more than fifty percent of the population of the world, that is, females are majority in number, but discriminated in all aspects of life, especially at different levels of education [5]. Education for girls and women has the potential to unlock the shackles of oppression and subjugation that avoid them from joining and contributing to society and living their fullest lives [6].

\section{Methodology}

This paper is primarily based on research conducted using qualitative approach. For the current study, the data is collected from reliable sources such UNICEF, UNESCO, Ministry of education, World Bank, National Education for All reports, Google Scholar, ERIC, ScienceDirect, Semantic Scholar and Research Gate, and numerous other genuine sources.

\section{Afghanistan and Low Ratio of Girls' Enrollment in Education}

Afghanistan is one of the poorest countries in the world located in the heart of central Asia. Afghanistan has suffered so hugely as compared to other countries that have experienced war for long periods. The devastation of the country was inconceivable leaving nearly nothing undistorted [7]. Within the frame of Islam, education has a long history in Afghanistan as in other Muslim countries and it contains three different categories such as traditional, modern and Islamic education. This is a justified fact that the educational participation in Afghanistan is the worst having one of the lowest literacy rates in the world, falling far behind neighboring countries because more than 4.5 million children were not allowed to participate in primary and secondary schools and girls constitute 60 percent of these children in the country [7]. Women's educational status, according to the writers, is lower than that of men, a situation that has to be modified if women are to become active participants in the reconstruction of Afghanistan. 
The significance of learning science and education for women is confirmed by Afghanistan's Islamic and education laws regardless of the physical and psychological threats and there are no legal barriers to women's education [8]. According to the Education Law (2016) [9] in Afghanistan's constitution, it is the basic right for all. It will signify the dissolution of a great number of barriers if Afghan girls rightly attain equitable access to education [6]. However, Afghan women do not take effective advantage of their constitutionally guaranteed equal protection under the law because there is a lack of legal awareness [10]. Afghanistan has made progress in education aspect over the last two decades and strong demand is available toward education among the majority of the public of Afghanistan, especially in improving girls' education [11]. However, education, according to Pherali and Sahar (2018) [12], has become a major victim of Afghanistan's prolonged crisis that involves fragile democracy and rising radicalization. The amount of girls' participation in education is declining in comparison to the past in some parts of Afghanistan and the goal set for girls' education is far from being met [13].

Resistance to girls' education dates back to the time of King Amanullah (1919) when women remained within the four walls of the house and have been absent from the public eye [13]. Women's status, according to the author, slightly changed and girls were allowed to attend schools. The first school for girls established in Kabul was in 1921 during the reign of King Amanullah [14]. Education for Afghan girls remains an indefinable dream because of more than thirty years of uninterrupted conflict and children without access to school defined being unable to share in this dream of what education can help to achieve [6] [15]. An out-of-school girl in Nangarhar said, "I am thinking about my future because I was supposed to be a teacher in the future, but I could not reach to my desire. I am unhappy and concerned about my fate" [15]. The following are some plain hurdles that limit girls' access to education despite the immense attributes to education.

\subsection{Traditional Challenges}

Traditional limitation, according to Khan (2020) [16], is a leading impediment in keeping the girls away from schools. Due to some certain predominant rigid cultural and traditional norms, girls with the age of 15, especially those of Pashtun ethnicity, were out of school. To be more specific, families from this particular tribe usually prefer educating boys over girls. Particularly those girls are less likely to attend schools whose parents are uneducated [16]. According to Shayan (2015) [11], dominant groups think that their job is to shelter the tradition. There is a traditional value among Pashtuns in the southeastern part of the country named "Pashtunwali", a tribal code. Girls in this region are only permitted to attain traditional education and attend Madrasa. There is a very well-known proverb among Pashtuns that says, "Woman is either for home or grave". Therefore, this practice has kept the girls alienated from attaining education [11]. 
With regard to girls' access to schools, there is at least one upper secondary girls' school in 151 rural districts out of 412; the others do not have any upper secondary girls' school. This clearly implies that there are some traditional norms dominated peoples' mindset [11]. To delve more into traditional norms, boys' education is given more preference over girls' education, especially girls who live in rural areas face these issues (UNESCO, 2012; Bamik, 2018) [13] [17]. Normally, husband is the leader of the family and is responsible for the home, therefore, girls' education is considered less important.

\subsection{Early Marriage Challenges}

As a result of illiteracy, more than half of the girls are getting married in Afghanistan before reaching their legal age [13]. Bamik also stated that the early marriage leaves many girls out of education where a third of the girls in this country marry before they turn 16. Whereas, the minimum age for a girl's marriage in Afghan Constitutional Law is stipulated 16, but the law is rarely practiced and less enforced. As a result of early marriage, they have to take care of their domestic responsibilities and motherhood [11]. According to Paktin (2013) [10], the issue of early marriage has been linked with social and cultural issues, but economy also plays its major role. The general expectation, according to the researcher, is "It is enough for girls just to be able to read and write, more than this is unnecessary".

\subsection{Logistical Challenges}

The girls have greater access to education as compared to the Taliban regime, access to education for girls is, however, restricted by powerful factors in spite of legislation and funding. These obstacles are physical, structural and geographical [6]. According to the author, 80 percent of the girls' schools were shut down in the country between 2007 and 2009. The writer further added that even the Afghan girls live in proximity to school that is physically sound and operating with necessary recourses, getting to and returning from that school presents its difficulties such as hazardous roads and inhospitable terrain. In addition to that, Roof (2015) [18] also raised the issue of insufficient facilities as a major barrier for girls in a carried out study. For example, majority of the families disagree to allow their girls to schools unless there is infrastructure, furniture, surrounding walls and other basic and indispensable facilities like drinking water, toilets with water to manage their menstrual hygiene [19] [20]. Similarly, health concerns and lack of appropriate sanitary provisions at the relevant schools are the reasons many parents deny allowing their girls to get education, even if they are supporters of girls' education in principle [21]. Lack of school textbooks is another concerning issue for girls who become uninterested and then leave school [22].

\subsection{Shortage of Same-Gender Teachers}

With only 40.7 percent of female teachers which is a tangible concern, is another 
contributing factor of low participation of girls in education [23] and it is a major challenge for the development of Afghanistan because Afghan society is typically patriarchal [11]. Regarding the beliefs of Afghan people, the author adds that parents totally disagree to allow their girls to attend school where male teachers also teach the girls. More girls, a survey carried out by Dryden-Peterson (2009) [15], would have been completed primary school if there have been female teachers recruited. The cause of low level of girls' participation is lack of female teachers at schools [10]. In addition to that, Shayan (2015) [11] confirmed that majority of the teachers now at schools are unqualified and do not have a degree.

\section{Pakistan and Low Ratio of Girls' Enrollment in Education}

Pakistan, a neighbor country of Afghanistan, is a developing country with a large population and the majority of the population creates women [24]. Pakistan is an Islamic society that pledges equal rights for both men and women [1]. However, lack of women's rights, education, centuries-old social and cultural taboos economic backward and nonexistence of opportunities for their steady development are issues that Pakistan still struggles with. The literacy rate of Pakistan is 50 percent, especially girls' literacy rate in rural areas is 25 percent and girls' enrolment in formal education decreased from 55 percent to 20 percent from grades 1 to 6 [3] [25]. In Pakistan, education can be characterized by widespread gender inequalities, that is, women are faced with socio-cultural obstacles to attain education [26]. The reason for low literacy rate in Pakistan is predominantly the shortage of resources for education purposes and shortage of awareness on the need for education in the people [24].

The condition for girl's education in Pakistan is worse than the boys because many people in Pakistan do not consider girls' education as important as for males [24] [27]. However, the government of Pakistan is now working to improve the status of women in society and avoid problems by making the law to punish accountable people. In addition to that, the constitution of Pakistan (1973) clearly states "Equal rights to all citizens, repudiates discrimination on the basis of sex alone and affirms steps to ensure full participation of women in all sphere of life" [27]. The following are the immense obstacles that limit girls' access to schools.

\subsection{Poverty}

Chronic poverty is a fundamental impediment in girls' education, especially the Pashtun region is stricken the most [25]. According to Jamal, the girls are encouraged to stay either at home to assist their mothers with house chores, or go out and bring some woods for fire, water and take care of cattle. Most importantly, extreme poverty is also the main contributing factor in early marriage that girls are usually forced to stop attending schools because marriage to some extent lightens families' economic burden [5] [25]. Similarly, Naz and Chaudhry 
(2011) [28] enumerated poverty acted as a potential barrier to girls' education to a greater extent in Pashtun society.

\subsection{Role of Cultural Norms}

Cultural values of the society is another obstacle to girls' education. The impact of cultural values of the society interacts for determining the level of female education in Pakistan (Malik \& Nawaz, 2016) [3]. To be more precise, the authors added "It is a cultural norm in Pakistan that females cannot take decisions about their lives. Usually parents and their brothers make decisions about their future lives". Considering the cultural norms of the society, it is also not easy for girls to survive in co-education system because they might face several other issues (Malik \& Nawaz, 2016) [3]. According to Jamal (2016) [25], there is a tribal code called "Pashtunwali" which means men's honor and dignity of family substituting many other priorities. The girls are confined within homes and have predetermined roles and responsibilities according to this code. For example, homemaking, preparing food, and childbearing do not support their education. Similarly, Mustafa, Khan and Jameel (2016) [24] also found the narrow mindset of the society as the main reason for girls not attending schools.

\subsection{Early Marriages}

Many studies [24] [27] have shown that early marriages of girls, is one of the major issues on their education. According to Nargis (2012) [5], marriage of a girl is the second name of respect and contentment of desires in Muslim community. Early marriage for a girl, according to the researchers, is based on the assumption that good marriage is the most essential way to secure girl's happiness and respect. The writers further added that it is the responsibility of most Pakistani parents to make early arrangements of girls' marriage. Because a young girl's place is seen at home in many cultures and she does not have the same position, same capabilities and perceived invaluable in educating her as compared to her male peers. Considering these disadvantages, this unavoidably bestows to the vision that a "good marriage" is the most important way to secure a girl's well-being [5]. The restrictions in pursuing education after the marriage are decided by her husband and in-laws [25]. In addition to that, the parents believe that girls are expected to get married and leave the family one day; therefore, parents consider girls' education a financial loss [3]. Likewise, Mustafa, Khan and Jameel (2016) [24] also raised the issue of girls' early marriages which restricts them from attending schools.

\section{Theoretical Framework}

This study is based on Maslow's theory of hierarchy of needs developed by Abraham Maslow in 1943 to examine girls' education. This theory consists of five stages. If one meets the lower stage needs, individual can progress higher stages [29]. This theory is applicable in this study because it illustrates how the girls are 
deprived of their needs and how their education is affected.

According to Rasheed et al. (2019) [30], the first stage of hierarchy need is physiological needs which consists some basic requirements for survival. This was true for the girls in the study areas where many girls are deprived of attending school because their parents are poor and they cannot afford to support the school expenses. Therefore, some girls were encouraged to stay at homes and do house chores, or go out and bring some drinking water or woods.

The second stage in hierarchy needs is safety needs which include fear free environment, protection, law, order, limits, and etc. This is regrettably true that many girls feel insecure while going to school. That is, the roads are very risky and the terrains are very hostile. The third stage includes social needs which represents love, belong to a group, family and social relationship. In both countries, especially the Pashtun communities, tended to deprive these substantial requirements. To be more precise, the young girls are not allowed to attend school, but they are forced for early marriages. Maslow's fourth stage is called "esteem stage". This stage represents self-respect, self-worth, attention, prestige and recognition. When people in this stage meet their needs, they feel confident and stable. However, both Afghan and Pakistani girls are deprived of these needs. This low esteem has affected their education. Boys are considered patrician in the family. In Maslow's theory, the topmost in the pyramid is self-actualization. That is, one strives to achieve one's full potential. If girls fail to achieve the needs in lower stages because they lack motivation and support from the family and society, it will affect their enrollment in education.

Figure 1 shows the main factors leading to low access to education.

\section{Factors}

\section{Cultural Norms}

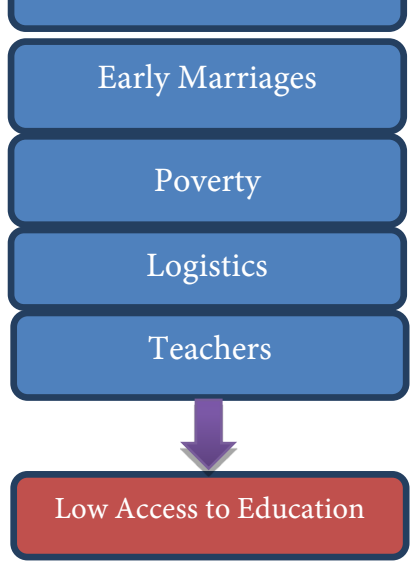

Figure 1. Conceptual framework.

\section{Conclusion}

Education is considered as a capital investment and has paramount importance for socio-economic development of a country. Females in Afghanistan and $\mathrm{Pa}$ - 
kistan are the most underprivileged and their enrollment ratio is significantly low, especially in majority of the Pashtun communities. Despite the two countries are Islamic countries and there are no barricades for girls' education in Islam, but still in some specific communities, girls are unable to attend schools. Meanwhile, the two countries struggle with introducing different policies to remove barriers towards girls' education, but they all seem fruitless. This paper is primarily meant to gather reasons and insights into girls' education in these two countries. The societal approach and cultural norms (Pashtunwali) regarding girls' education and poverty seem to be potent problems. The current literature from both countries also concluded that early marriages, immense scarcity of female teachers in remote areas, and logistical and infrastructural limitations have been identified as the obscuring factors in terms of girls' education.

\section{Recommendations}

It is recommended that there is a need for a substantial paradigm shift in the way that government, should plan how to increase the number of female education trends by forming partnerships with NGOs and donor agencies by providing a suitable setting where at least the necessary facilities such as classrooms, drinking water, and gender-sensitive facilities would be accessible for girls' education. Also, with the help of these partnerships, the State should address the poverty-education issues by providing incentives for girls.

Also, the government of Afghanistan and Pakistan to take practical actions to escalate the enrollment ratio. In this regard, the governments have to involve Mullahs in mosques to launch an immense public awareness campaign and preach the importance of girls' education and their right to education in accordance with Islamic law, education law and Afghan constitution on Fridays. Similarly, Mullah's preach has a strong contribution to eliminating parents' negative beliefs about boys' preference over girls' education. Likewise, the local directorates should have key strategies for promoting girls' education by creating Shura (board or community council) comprised of Mullahs, local religious leaders because they have a substantial influence on people, and collaboration of students' parents in schools to encourage them to allow females for getting education.

In addition to that, the two governments should increase the number of qualified teachers in remote areas. Instead of halting girls from attending schools, the people of the two nations should strengthen communities' sense of responsibility and fight with predominant social and cultural norms to secure girls' well-being. In this regard, the government is also required to involve religious scholars and ask them to change the perception of the society and promote girls' education.

\section{Conflicts of Interest}

The authors declare no conflicts of interest regarding the publication of this paper. 


\section{References}

[1] Fatima, G. (2011) Female Education as a Determinant of Economic Growth: The Case Study of Pakistan. Contemporary Issues in Education Research, 4, 15-22. https://doi.org/10.19030/cier.v4i11.6485

[2] Daraz, A.N.U., Khan, W. and Sheikh, I. (2013) Physical and Infrastructural Obstacles to Women's Education in Khyber Pakhtunkhuwa Pakistan. FWU Journal of Social Sciences, 7, 139-145.

[3] Malik, Z. and Nawaz, A. (2016) Female Education Problems in Pakistan. Journal of Educational Science and Research, 6, 1-4.

[4] Baiza, Yahia (2014) Suksesser og utfordringer [Success and Challenges (of Education in Afghanistan, 2002-13)]. In: Afghanistan 2014: Et temahefte [Afghanistan 2014: A Pamphlet], Norwegian Afghanistan Committee, Oslo, 26-29.

[5] Nargis, A.R.A. (2012) Gender Discrimination in Education-A Barrier in Development of Female Education at Higher Secondary Level. Interdisciplinary Journal of Contemporary Research in Business, 4, 330-339.

[6] Kissane, C. (2012) The Way Forward for Girls' Education in Afghanistan. Journal of International Women's Studies, 13, 10-28.

[7] Karlsson, P. and Mansory, A. (2008) Islamic and modern education in Afghanistan: Conflictual or complementary. Institute of International Education, Stockholm University, Stockholm.

[8] Haqmal, H. (2012) State of Women's Education in Afghanistan. In: The Role of Women and Gender in Conflict, Spanish Institute for Strategic Studies, Granada University, Granada, 210-242.

[9] Ministry of Education, Islamic Republic of Afghanistan (2016) Law of Education (Gazette No. 955). Afghanistan.

[10] Paktin, M. (2013) Female Participation in Paktia Teacher Training College of Afghanistan: Obstacles for Female Participation. Karlstad University, Karlstad.

[11] Shayan, Z. (2015) Gender Inequality in Education in Afghanistan: Access and Barriers. Open Journal of Philosophy, 5, 277-284.

https://doi.org/10.4236/ojpp.2015.55035

[12] Pherali, T. and Sahar, A. (2018) Learning in the Chaos: A Political Economy Analysis of Education in Afghanistan. Research in Comparative and International Education, 13, 239-258. https://doi.org/10.1177\%2F1745499918781882

[13] Bamik, H. (2018) Afghanistan's Cultural Norms and Girls' Education: Access and Challenges. International Journal for Innovative Research in Multidisciplinary Field, 4, 83-93.

[14] Vinson, J.E. (2008) Educating Girls and Empowering Women: Gender and PostConflict Educational Reform in Afghanistan.

[15] Dryden-Peterson, S. (2009) Barriers to Accessing Primary Education in Conflict-Affected Fragile States. Save the Children, London.

[16] Khan, A.B. (2020) Socio-Economic Barriers to Children's Education in Afghanistan: A Case Study of Kabul City. Journal of Business and Management Revolution, 1, $1-9$.

[17] UNESCO (United Nations Educational, Scientific and Cultural Organization) (2012) From Access to Equality-Empowering Girls and Women through Literacy and Secondary Education. United Nations Educational, Scientific and Cultural Organization, Paris.

[18] Roof, D.J. (2015) Day-by-Day: Higher Education in Afghanistan. FIRE: Forum for 
International Research in Education, 1, 64-80.

[19] Barr, H. (2017) “I Won't Be a Doctor, and One Day You'll Be Sick”: Girls’ Access to Education in Afghanistan. Human Rights Watch, New York.

[20] Noori, A. (2017) Issues Causing Girls' Dropout from Schools in Afghanistan. International Journal for Innovative Research in Multidisciplinary Field, 3, 111-116.

[21] Rubin, B. and Rudeforth, C. (2016) Enhancing Access to Education: Challenges and Opportunities in Afghanistan. Center in International Cooperation, New York University, New York.

[22] Shafique, M. (2013) Why Do Students Drop Out? A Study of Boys' and Girls' Drop out in Primary Schools, Jalalabad City, Nangarhar Province, Afghanistan.

[23] Ministry of Education (2015) National Education Strategic Plan (2017-2021). Department of Planning and Evaluation, Ministry of Education, Deh Afghanan.

[24] Mustafa, S., Khan, M.S.A. and Jameel, K. (2016) Women Education in Pakistan: Is the Level Enough for Empowerment? International Journal of Scientific \& Engineering Research, 7, 1747-1753.

[25] Jamal, A. (2016) Why He Won't Send His Daughter to School-Barriers to Girls' Education in Northwest Pakistan: A Qualitative Delphi Study of Pashtun Men. SAGE Open, 6, 1-14. https://doi.org/10.1177\%2F2158244016663798

[26] Alam, S. (2017) Female Education: The Facilitating and Hindering Factors Regarding Female Education in Gilgit-Baltistan Context of Pakistan. International Women Online Journal of Distance Education, 6, 35-52.

[27] Noureen, G. and Awan, R. (2011) Women's Education in Pakistan: Hidden Fences on Open Frontiers. Asian Social Science, 7, 79-87.

https://doi.org/10.5539/ass.v7n2p79

[28] Naz, A. and Chaudhry, H.U.R. (2011) Gender and Development: Socio-Cultural, Economic, Religious and Political Impediments in Women's Empowerment and Gender Development: A Case Study of Malakand Division KPK Pakistan. Bioinfo Sociology, 1, 15-24.

[29] Silas Mollel, N. and Chong, R. (2017) Socio-Cultural Constraints of Girls' Access to Education in Mtwara District, Tanzania. Khazar Journal of Humanities \& Social Sciences, 20, 108-125. https://doi.org/10.5782/2223-2621.2017.20.3.108

[30] Rasheed, E., Yu, J., Hale, S., Booth, N. and Shahzad, W. (2019) Explaining the Factors' Influencing Young Females' Interest in the Construction Industry Using Maslow's Hierarchy of Needs. 2019 West Africa Built Environment Research (WABER) Conference, Accra, 5-7 August 2019, 580-589. 